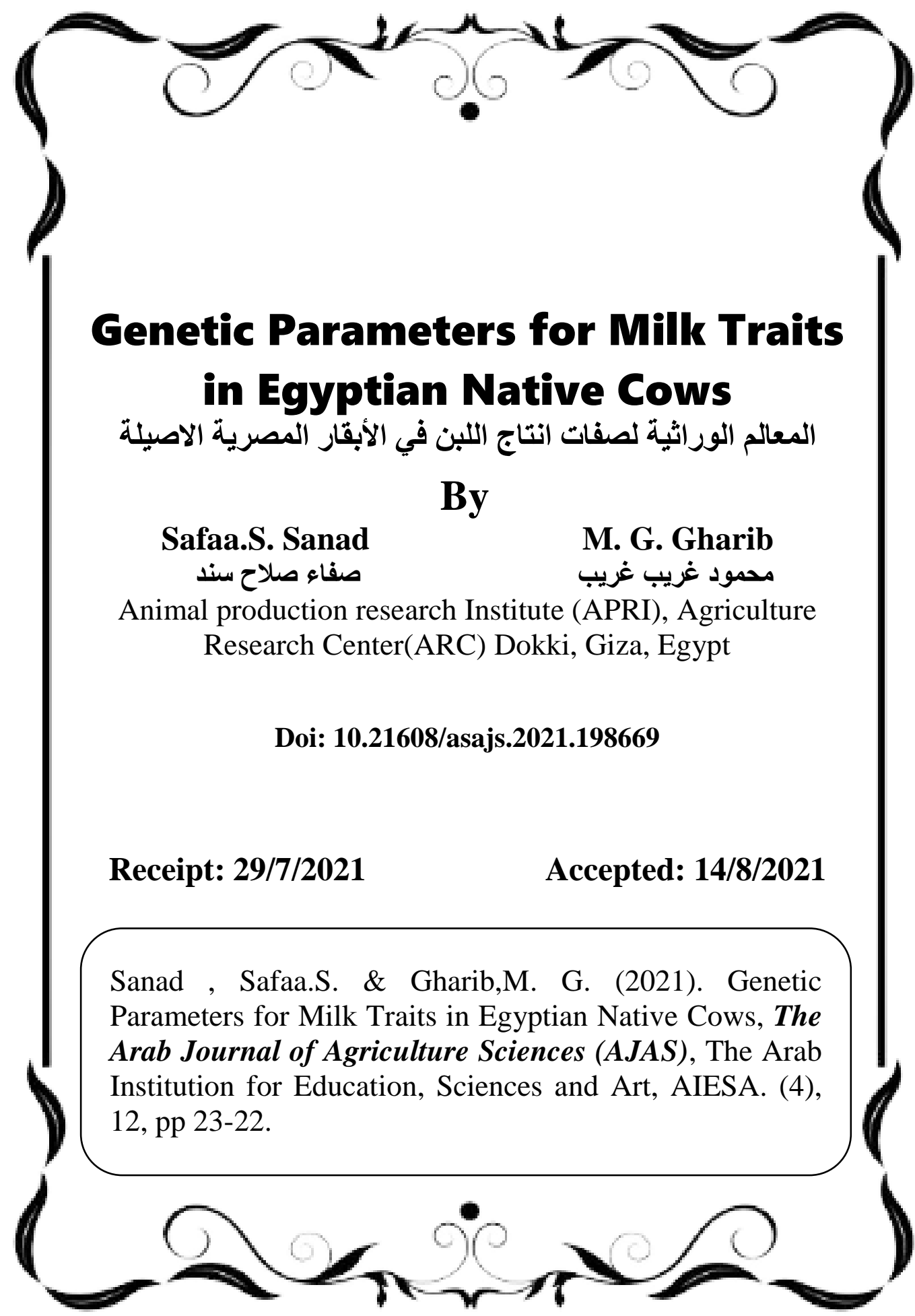


Genetic Parameters for Milk.. $] \quad$ Safaa Sanad-M. Gharib

\section{Genetic Parameters for Milk Traits in Egyptian Native Cows ABSTRACT:}

The aim of this study is to estimate the genetic parameters and the effect of non-genetic factors for some milk traits including total milk yield (TMY), Lactation period (LP), number of services per conception (NSC), days open (DO), calving interval (CI) and dry period (DP). Data were collected from two farms. Experimental Farm belonging to (APRI) data included 1829 records. The statistical analysis has been adopted using animal models. Actual means of TMY $/ \mathrm{kg}$, LP/day, NSC/services, DO/day, CI/day and DP/day were 791.3, 171.1, $1.8,109,402.7$ and 79.3 respectively. Estimated heritability $\left(\mathrm{h}^{2}\right)$ of TMY, LP, NSC, DO, CI, and DP were $0.18 \pm 0.01,0.15 \pm$ $0.001,0.07 \pm 0.016,0.05 \pm 0.001,0.09 \pm 0.041$ and $0.09 \pm 0.001$ respectively. While the range of $\mathrm{BV}$ of the cows was the highest for all traits $\mathrm{TMY} / \mathrm{kg}$, LP/day, NSC, /services, DO/day, CI/day and DP/day were $776.3,26.7,6.7,13.4,77.1$ and 11.5 respectively. The estimated Predicted Breeding Value PBV for all traits varied widely. The genetic trends of cow breeding values were significant for all studied traits. This confirms that the genetic improvement of these traits leads to increased milk production traits. The study recommends preserving the Native Egyptian dairy cattle because they represent a national wealth that must be preserved from extinction through inventorying the genetic resources, characterization and evaluation of this local breed to benefit from it in improving animal breeds of high economic value. Due to the distinction of Egyptian domestic cows for their resistance to various environmental conditions.

Keywords: Egyptian Native cattle, genetic trend, milk traits. 


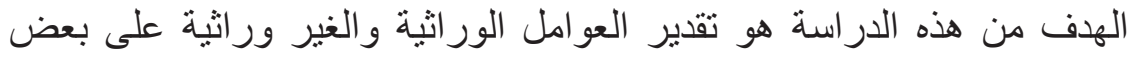

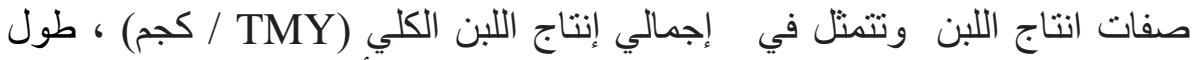

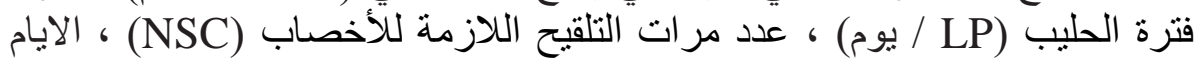

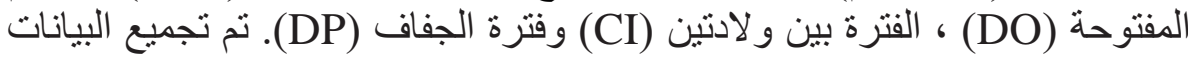

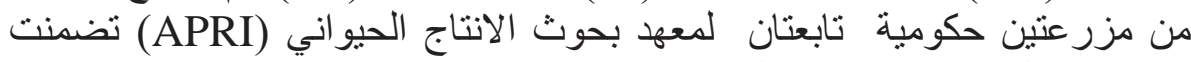

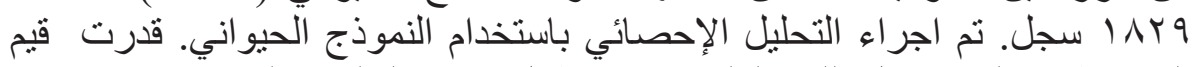

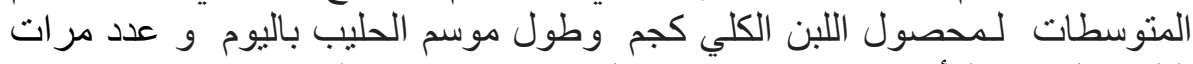

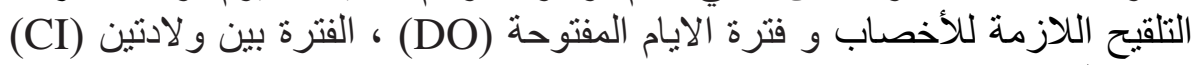

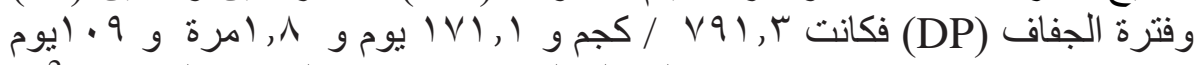

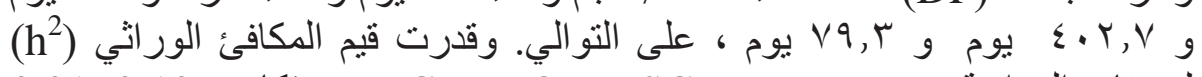

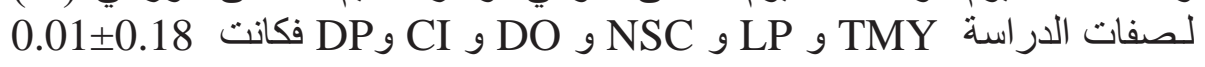
و

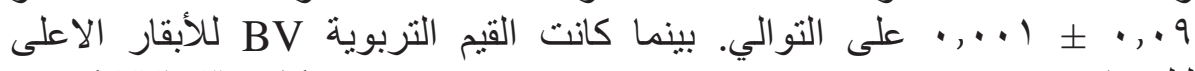

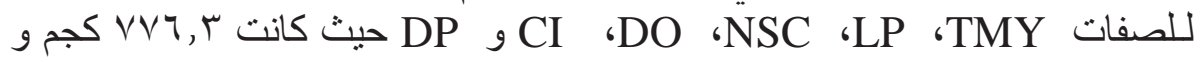

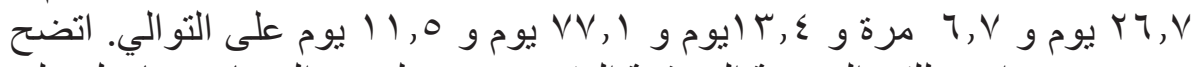

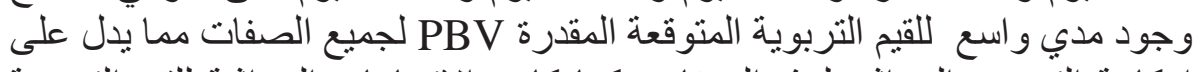

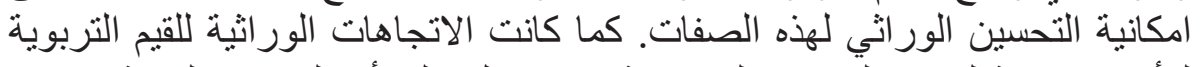

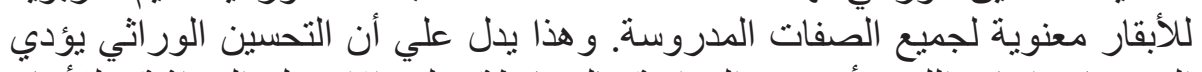

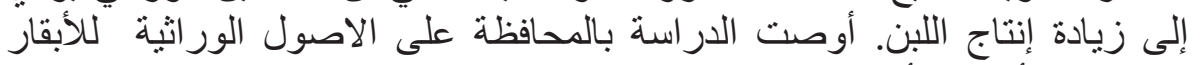

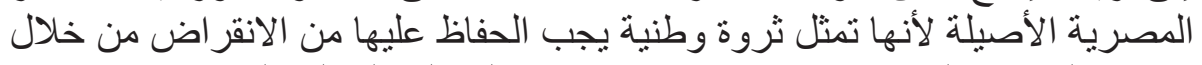

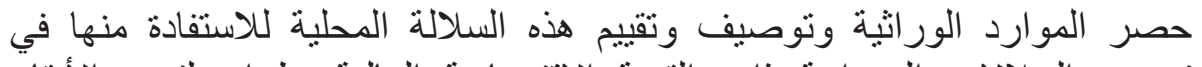

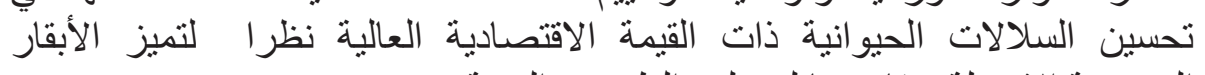

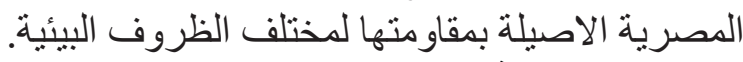
الكلمات المفتاحية: الماثية المصرية الإيلة الصيلة ، الاتجاهات الوراثية ، صفات انتاج اللبن.

\section{INTRODUCTION}

Egyptian cows are one of the local milk and meat producing breeds in Egypt. They have adapted to environmental conditions, but are threatened by extinction. The Native Egyptian dairy cattle differ in their traits and genetic breeding from global 
Genetic Parameters for Milk.. $/ \quad$ Safaa Sanad-M. Gharib

cattle and are kept for preservation of genetic assets. Native cows are a national wealth that must be preserved from extinction. In Egypt, the total Domiati cattle (Native Egyptian dairy cattle) is approximately 2.5 million. Proper management is crucial to determine the most important environmental factors affecting the productivity of the herd. Several investigators have screened some of the non-genetic and genetic factors of productive and reproductive traits of that breed under the Egyptian conditions (Abd-Elhamid (2018). The increase of production and reproduction efficiency is implemented by improving the environmental conditions of the animals and the breeding values of the herd. (Katkasame et al., 1996). Genetic trend is defined as a change in performance per unit of time, which is due to a change in the average breeding values and the direction of change indicates the extent of progress or decline that can be achieved as a result of the breeding plan used. (Ojango and Pollott,2001).There is a need for continuous evaluation of the effect of genetics on the parameters and trends in Egyptian cows (Amimo et al., 2007). The aim of the study is to address the effect of environmental conditions on milk traits and estimate the heritability, breeding value and genetic trends of Domiati (Native Egyptian dairy cattle). Based on the results of the study, appropriate decisions will be taken to improve herd performance with the goal of genetic improvement of these traits in the future.

\section{MATERIALS AND METHODS}

\section{Data source:}

The study applies a number of lactations 1829 , records of 311 cows, daughters of 118 dams and 69 sires for eight parity during a period from 1996 to 2020 in pure native Egyptian herd of Sids and El- Serw , two farms belonging to (APRI), Egypt as shown in Table 1. 
Structure of data : Table (1). Summary of Data available for analysis

\begin{tabular}{|cl|}
\hline Item & Number \\
\hline Record & 1829 \\
Cows & 311 \\
Sires & 69 \\
Dams & 118 \\
Farm & 2 \\
Parity & 8 \\
Year & $25(1996-2020)$ \\
Season & 4 \\
\hline
\end{tabular}

Management and strategy of feeding :

\section{Herd management}

Feeding policy was designated according to animals' body weight, production, and pregnancy. Clean water supply is available all the time. Egyptian clover is supplied during summer while some concentrates with silage and flag leaves (Darawa), the mineral salt mixture and vitamins are available all the year round. The cows are milked twice a day (morning and evening). Heifers were served at puberty at the age of about 18 months with a suitable weight of about $350 \mathrm{~kg}$, taking into account the presence of a veterinarian who supervises the health of the herd to follow up on the health status.

Studied traits: Total milk yield (TMY/kg), (LP/day) as (NSC/services), days open (DO), calving interval (CI) and dairy period (DP) were recorded.

Statistical analysis; Data was analyzed based on the procedure of SAS (2003).

The following statistical mixed model was used.

$\mathbf{Y}_{\mathrm{ifjklm}}=\mu+S_{\mathrm{i}}+\mathrm{L}_{\mathrm{F}}+\mathrm{P}_{\mathrm{j}}+\mathrm{SE}_{\mathrm{k}}+\mathrm{YR}_{\mathrm{l}}+\mathrm{L}_{\mathrm{F}} * \mathrm{SE}_{\mathrm{k}}+\mathrm{YR}_{\mathrm{l}} * \mathrm{SE}_{\mathrm{k}}+$ $\mathbf{P}_{\mathbf{j}} * \mathrm{SE}_{\mathrm{k}}+\mathbf{e}_{\mathrm{itFjklm}}$ where, 


\section{Genetic Parameters for Milk.. $[\quad$ Safaa Sanad-M. Gharib}

$\mathbf{Y}_{\mathrm{ifjk \textrm {k }}}=$ individual (observation), $\mu=$ overall means, $\mathrm{Si}=$ random effect of $i^{\text {th }}$ sire, $\mathbf{L}_{\mathbf{F}}=$ the fixed effect of $\mathrm{f}^{\text {th }}$ farm lacation, $\mathrm{Pj}=$ the fixed effect of $j^{\text {th }}$ parity of calving, $\mathrm{SE}_{\mathrm{k}}=$ fixed effect of $\mathrm{k}^{\text {th }}$ season of calving, $\mathrm{YR}_{\mathbf{l}}=$ the fixed effect of $1^{\text {th }}$ year of calving, $\mathbf{L}_{\mathbf{F}} * \mathbf{S E}_{\mathbf{k}}=$ the fixed effect of interaction between the $\mathrm{f}^{\text {th }}$ farm location and the $\mathrm{k}^{\text {th }}$ season of calving, $\mathbf{Y}_{\mathbf{R l}} * \mathbf{S E}_{\mathbf{k}}=$ the fixed effect of interaction between the $1^{\text {th }}$ year of calving and the $\mathrm{k}^{\text {th }}$ season of calving, $\mathbf{P}_{\mathbf{j}} * \mathbf{S E}_{\mathbf{k}}=$ the fixed effect of interaction between the $\mathrm{j}^{\text {th }}$ parity of calving and the $\mathrm{k}^{\text {th }}$ season of calving and $\mathbf{e}_{\mathbf{i t f j}} \mathbf{k} \mathbf{m}=$ the residual effect with $\mathbf{Y}_{\text {ifjklm }} \sim \mathrm{N}\left(0, \sigma^{2} \mathrm{e}\right)$.

\section{Genetic parameters:}

Estimates of $\left(\mathrm{h}^{2}\right)$ and BV of studied traits were estimated procedures using the single-trait Animal Model (STAM). Boldmanet al., (1995). The assumed model was:

$\mathbf{y}=\mathbf{X b}+\mathbf{Z}_{1} \mathbf{a}+\mathbf{Z}_{2} \mathbf{p}+\mathbf{e}$, where; $\mathbf{y}=$ vector of observations, $\mathbf{b}=$ vector of fixed effect, while a, p and e are = vectors of direct additive (genetic effect), permanent environmental effect and the residual effect respectively, $\mathrm{X}, \mathrm{Z}_{1}$ and $\mathrm{Z}_{2}=$ incidence matrix relating individual records.

\section{RESULTS AND DISCUSSION}

Actual means of TMY $/ \mathrm{kg}, \mathrm{LP} /$ day, NSC/ services, DO/ day, CI/ day and DP/ day were 791.3, $171.1,1.8,109,402.7$ and 79.3 respectively. The mean of TMY for native Egyptian cows was $791 \mathrm{~kg}$ lower than $1078 \mathrm{~kg}$, which was found by AbdElhamid (2018) and Khalifa Zeinab (1994), which achieves $1212 \mathrm{~kg}$ on Baladi herd. In addition, the average of LP for Baladi cows was 171 day which was lower than those found by Abd-El hamid (2018), 324 day and Khalifa Zeinab (1994), 313 day, while El-Shabory (2009) found that means of LP for Baladi was 164 day. 


\begin{tabular}{|c|c|c|c|c|}
\hline \multicolumn{3}{|c|}{ 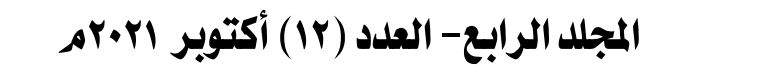 } & \multicolumn{2}{|c|}{ المجلة العربية للعلوه الزراعية } \\
\hline \multicolumn{2}{|c|}{$\begin{array}{l}\text { Table 2. Means, SD } \\
\text { cows. }\end{array}$} & \multicolumn{3}{|c|}{ and CV\% for study traits of Baladi } \\
\hline Traits & No. & (Mean) & $(\mathrm{SD})$ & $(\mathrm{CV} \%)$ \\
\hline TMY $(k g)$ & 1829 & 791.3 & 330.9 & 41.8 \\
\hline LP(Day) & 1829 & 171.1 & 52.5 & 30.5 \\
\hline $\mathrm{NSC}($ services) & 1829 & 1.76 & 0.61 & 34.8 \\
\hline DO(day) & 1829 & 109.0 & 22.4 & 205 \\
\hline CI(day) & 1516 & 402.7 & 94.8 & 23.5 \\
\hline DP(day) & 1516 & 79.3 & 12.6 & 15.8 \\
\hline
\end{tabular}

(SD) =standard deviations and $(\mathrm{CV} \%)=$ coefficients of variation. The values of the CV\% were generally higher for all traits under this study. This reflects a large deal of variations among cows. Therefore we expect genetic improvement during selection program. These differences among the study estimates and those of other studies may be due to one or more of these reasons: different managerial conditions and climatic, phenotypic and Genetic differences, different models and methods of analysis used and whether some animals were locally produced or imported. Safaa and Hassananen(2019) and Safaa Sanad and Gharib(2021).

\section{Nongenetic factors:}

Non genetic factors affecting milk traits in this study are shown in table 3 . It shows that the effect of location, parity, year and season of calving had highly significant effect $(\mathrm{P}<0.001)$ on all milk production traits under study. The interaction between parity and season was a significant effect $(\mathrm{P}<0.05$ or $\mathrm{P}<0.001)$ on TMY, LP, DO and DP traits, while the interaction between year and season was a significant effect $(\mathrm{P}<0.05$ or $\mathrm{P}<$ 0.01 or $\mathrm{P}<0.001)$ on TMY and DO traits. However, The interaction between location and season was a significant effect $(\mathrm{P}<0.05$ or $\mathrm{P}<0.001)$ on $\mathrm{CI}$ and $\mathrm{DO}$ traits. The study results were in agreement with those obtained by Amr (2013) and 
Safaa Sanad (2016) who reported that the farm had a highly significant effect on milk production traits. These differences among farms may be due to the difference in genetic structure among herds, management practices applied, and the different environmental and climatic conditions due to different regions that affect the adaptation of the cows. The present data in table 3 , indicate that winter (December, January and February) were the highest compared to the previous year. Results also indicate that the longer $\mathrm{CI}$ and DO were found in cows calving in winter. According to El-Awady and Oudah (2012) the highest yield was in spring and winter because green fodder such as Egyptian clover is available during (December through May) in addition to proper management, which is followed by increased productivity, while in summer and autumn the milk yield decreases due to the inappropriate environmental conditions (heat, humidity) and the decrease in feed intake (green fodder) during this period. With Domiati, Arafa, Samira (1987) found that the least squares mean of LP for winter, spring, summer and autumn were 277, 296, 390 and 287/day respectively. The effect of year of calving on studying traits could be due to different nutritional and managerial practices present within different years. In the current study, year of calving and genotype groups had a highly significant effect on all traits $(\mathrm{P}<0.01)$. The difference between the authors in estimating the traits of the milk may be due to the following reasons (different number of herds, genetic potentiality changes and management practices, variability of climatic). The difference in milk traits among different authors may be attributed to genetic potentiality of the different number of herds or referring to variability of climatic changes and management practices. Non-genetic factors had highly significant $(\mathrm{p}<0.01)$ impact on all study traits. Similar results have been reported by Safaa Sanad (2016) and Abd-EI hamid (2018). Some previous research has shown significant 
effects for the year and season of birth, number of seasons, and age of the cow at birth on milk production. (Pantelic et al., 2014; Petrovic, et al., 2015), while other studies showed nonsignificant effects (Ozkan and Gunes, 2011). Also, significant effects were found during the milking season (Pantelic al et.2014 and 2013). Proper dairy herd management include an increase in the herd (farm size), and in the use of the technologies (insemination) to aid in improving fertility management, and genetic selection (breeding programs and phenotypes of animals). Nutritional management should be accompanied by the control of infectious diseases, rapid reproductivity diagnostics, fertility improvements, and improved breeding protocols. These factors should facilitate and improve performance, productivity, reproductivity and health of Baladi cows in the future. Egyptian cattle (Native Egyptian dairy cattle) need to be selected and improved to become highly productive, in addition to the importance of care (cleanliness, convenient housing, healthy proper milking, concentrate feeding to compensate for the nutrients lost from the body through milking, pregnancy fetus, calving and etc.)

Table 3. Least square means LSM \pm standard Error SE for factors affecting study traits in Baladi cows

\begin{tabular}{|c|c|c|c|c|c|c|c|c|}
\hline & No. & TMY(kg) & LP(Day) & NSC(day) & DO & No. & $\mathrm{CI}$ (day) & DP \\
\hline \multicolumn{9}{|l|}{ farm locati } \\
\hline Sids & 1209 & $823.2 \pm 21.7$ & $176.6 \pm 3.4$ & $1.8 \pm 0.04$ & $110.1 \pm 1.3$ & 1139 & $408.52 \pm 6.9$ & $79.5 \pm 0.9$ \\
\hline El- Serw & 620 & $796.9 \pm 23.8$ & $165.6 \pm 3.7$ & $1.6 \pm 0.05$ & $105.8 \pm 1.5$ & 377 & $392.4 \pm 8.1$ & $77.7 \pm 1.1$ \\
\hline Sig. & & $*$ & $* * *$ & $* * *$ & $*$ & & ns & ns \\
\hline \multicolumn{9}{|l|}{ Parity } \\
\hline$\overline{1}$ & 186 & $743.4 \pm 32.2$ & $158.4 \pm 5.0$ & $1.9 \pm 0.06$ & $113.5 \pm 2.1$ & & - & - \\
\hline 2 & 234 & $795.3 \pm 28.3$ & $168.1 \pm 4.4$ & $1.7 \pm 0.05$ & $110.8 \pm 1.9$ & 107 & $414.5 \pm 11.7$ & $79.0 \pm 1.6$ \\
\hline 3 & 238 & $833.7 \pm 29.5$ & $172.5 \pm 4.6$ & $1.7 \pm 0.05$ & $109.1 \pm 1.9$ & 238 & $400.9 \pm 9.0$ & $78.3 \pm 1.2$ \\
\hline 4 & 251 & $863.9 \pm 30.1$ & $177.5 \pm 4.7$ & $1.7 \pm 0.05$ & $109.4 \pm 1.9$ & 251 & $391.7 .8 \pm 9.2$. & $78.5 \pm 1.2$ \\
\hline 5 & 256 & $814.6 \pm 27.3$ & $182.0 \pm 4.2$ & $1.7 \pm 0.05$ & $101.5 \pm 1.7$ & 256 & $394.2 \pm 8.3$ & $80.3 \pm 1.1$ \\
\hline 6 & 322 & $803.7 \pm 26.0$ & $178.3 \pm 4.0$ & $1.6 \pm 0.05$ & $97.9 \pm 1.7$ & 322 & $401.5 \pm 8.0$ & $78.6 \pm 1.1$ \\
\hline 7 & 224 & $797.3 \pm 28.1$ & $177.0 \pm 4.3$ & $1.8 \pm 0.05$ & $108.5 \pm 1.8$ & 224 & $405.0 \pm 8.5$ & $78.2 \pm 1.1$ \\
\hline
\end{tabular}




\section{Genetic Parameters for Milk.. $[\quad$ Safaa Sanad- M. Gharib}

\begin{tabular}{|c|c|c|c|c|c|c|c|c|}
\hline $\begin{array}{c}8 \\
\text { Sig }\end{array}$ & 118 & $\begin{array}{c}720.5 \pm 37.7 \\
* *\end{array}$ & $\begin{array}{c}154.8 \pm 5.9 \\
* * *\end{array}$ & $\begin{array}{c}1.5 \pm 0.07 \\
* * *\end{array}$ & $\begin{array}{c}114.1 \pm 2.1 \\
* * *\end{array}$ & 118 & $\begin{array}{c}395.3 \pm 11.3 \\
n s\end{array}$ & $\begin{array}{l}77.5 \pm 1.5 \\
n s\end{array}$ \\
\hline \multicolumn{9}{|l|}{ Season } \\
\hline$\overline{\text { Autumn }}$ & 511 & $760.6 \pm 27.6$ & $165.1 \pm 4.3$ & $1.7 \pm 0.05$ & $108.7 \pm 1.7$ & 430 & $420.0 \pm 9.5$ & $78.5 \pm 1.3$ \\
\hline Winter & 409 & $844.9 \pm 26.9$ & $180.3 \pm 4.2$ & $1.7 \pm 0.05$ & $105.2 \pm 1.7$ & 330 & $398.4 \pm 9.6$ & $80.0 \pm 1.3$ \\
\hline Spring & 801 & $812.3 \pm 27.2$ & $169.4 \pm 4.2$ & $1.8 \pm 0.05$ & $104.9 \pm 1.8$ & 363 & $389.4 \pm 10.0$ & $78.3 \pm 1.3$ \\
\hline $\begin{array}{c}\text { Summer } \\
\text { Sig. }\end{array}$ & 511 & $\begin{array}{c}768.4 \pm 22.2 \\
*\end{array}$ & $\begin{array}{c}169.4 \pm 4.2 \\
* * *\end{array}$ & $\begin{array}{c}1.7 \pm 0.05 \\
*\end{array}$ & $\begin{array}{c}113.1 \pm 1.7 \\
* * *\end{array}$ & 393 & $\begin{array}{c}394.0 \pm 89 \\
\mathrm{~ns}\end{array}$ & $\begin{array}{l}78.2 \pm 1.2 \\
\text { ns }\end{array}$ \\
\hline \multicolumn{9}{|l|}{ Year } \\
\hline 1996 & 131 & $765.2 \pm 37.1$ & $169.7 \pm 5.8$ & $1.4 \pm 0.07$ & $109.6 \pm 2.3$ & 114 & $364.0 \pm 11.8$ & $76.6 \pm 1.6$ \\
\hline 1997 & 120 & $873.0 \pm 35.6$ & $168.6 \pm 5.5$ & $1.5 \pm 0.08$ & $106.7 \pm 2.2$ & 101 & $406.5 \pm 11.4$ & $77.6 \pm 1.5$ \\
\hline 1998 & 35 & $705.0 \pm 63.4$ & $169.6 \pm 9.8$ & $1.2 \pm 0.12$ & $109.4 \pm 3.9$ & 18 & $407.1 \pm 25.5$ & $73.7 \pm 4.0$ \\
\hline 1999 & 72 & $704.3 \pm 49.4$ & $177.6 \pm 7.7$ & $1.4 \pm 0.09$ & $107.0 \pm 3.0$ & 65 & $342.2 \pm 15.3$ & $81.4 \pm 2.0$ \\
\hline 2000 & 54 & & $151.8 \pm 11$ & $1.6 \pm 0.14$ & & 46 & & \\
\hline & & $683.6 \pm 76.2$ & 8 & & $110.3 \pm 4.7$ & & $356.1 \pm 238$ & $81.3 \pm 3.2$ \\
\hline 2001 & 74 & $738.0 \pm 47.6$ & $168.9 \pm 7.4$ & $1.5 \pm 0.10$ & $110.9 \pm 2.9$ & 64 & $406.1 \pm 15.2$ & $79.6 \pm 1.5$ \\
\hline 2002 & 120 & $809.3 \pm 35.7$ & $174.4 \pm 5.5$ & $1.5 \pm 0.07$ & $109.8 \pm 2.2$ & 102 & $423.7 \pm 11.5$ & $79.4 \pm 1.5$ \\
\hline 2003 & 31 & & $156.0 \pm 11$ & $1.2 \pm 0.14$ & & 29 & & \\
\hline & & $640.8 \pm 72.7$ & 3 & & $113.2 \pm 4.5$ & & $393.0 \pm 22.1$ & $75.2 \pm 2.9$ \\
\hline 2004 & 24 & $823.6 \pm 80.8$ & $\begin{array}{c}154.0 \pm 12 \\
6\end{array}$ & $1.4 \pm 0.15$ & $93.8 \pm 5.0$ & 16 & $441.1 \pm 39.6$ & $83.6 \pm 5.3$ \\
\hline 2005 & 83 & $818.5 \pm 41.4$ & $180.8 \pm 6.4$ & $1.6 \pm 0.08$ & $107.7 \pm 2.6$ & 66 & $418.0 \pm 13.4$ & $79.8 \pm 1.8$ \\
\hline 2006 & 73 & $809.4 \pm 44.3$ & $181.3 \pm 6.9$ & $1.7 \pm 0.08$ & $105.3 \pm 2.7$ & 66 & $407.6 \pm 13.7$ & $78.2 \pm 1.8$ \\
\hline 2007 & 52 & $775.4 \pm 54.4$ & $186.3 \pm 8.5$ & $1.6 \pm 0.10$ & $110.4 \pm 3.4$ & 45 & $399.2 \pm 16.6$ & $79.9 \pm 2.2$ \\
\hline 2008 & 40 & $774.2 \pm 62.4$ & $177.7 \pm 9.7$ & $1.6 \pm 0.12$ & $110.0 \pm 3.8$ & 34 & $407.6 \pm 19.1$ & $76.6 \pm 2.5$ \\
\hline 2009 & 134 & $783.5 \pm 34.8$ & $174.9 \pm 5.4$ & $1.7 \pm 0.07$ & $106.5 \pm 2.1$ & 120 & $417.2 \pm 10.9$ & $80.4 \pm 1.5$ \\
\hline 2010 & 67 & $908.8 \pm 54.9$ & $164.1 \pm 8.5$ & $1.4 \pm 0.10$ & $110.0 \pm 3.4$ & 45 & $408.6 \pm 18.5$ & $79.0 \pm 2.5$ \\
\hline 2011 & 157 & $864.5 \pm 35.1$ & $171.9 \pm 5.5$ & $1.5 \pm 0.07$ & $108.8 \pm 2.2$ & 116 & $392.8 \pm 12.2$ & $80.0 \pm 1.6$ \\
\hline 2012 & 100 & $718.5 \pm 37.9$ & $158.8 \pm 5.8$ & $2.0 \pm 0.07$ & $108.8 \pm 2.3$ & 83 & $411.6 \pm 12.5$ & $77.5 \pm 1.7$ \\
\hline 2013 & 236 & $831.0 \pm 28.5$ & $178.7 \pm 4.4$ & $2.1 \pm 0.05$ & $108.5 \pm 1.8$ & 202 & $412.0 \pm 9.0$ & $78.8 \pm 2.0$ \\
\hline 2014 & 40 & & $175.5 \pm 10$ & $2.3 \pm 0.13$ & & 36 & & \\
\hline & & $700.9 \pm 66.3$ & 3 & & $111.3 \pm 4.1$ & & $424.2 \pm 21.1$ & $80.0 \pm 2.8$ \\
\hline 2015 & 51 & $764.5 \pm 55.1$ & $171.2 \pm 8.6$ & $2.1 \pm 0.10$ & $104.0 \pm 3.4$ & 46 & $416.1 \pm 16.7$ & $78.8 \pm 2.2$ \\
\hline 2016 & 44 & $959.8 \pm 57.2$ & $183.4 \pm 8.9$ & $2.1 \pm 0.11$ & $107.4 \pm 3.5$ & 41 & $411.5 \pm 17.2$ & $81.0 \pm 2.3$ \\
\hline 2017 & 17 & & $177.7 \pm 12$ & $2.1 \pm 0.11$ & & 15 & & \\
\hline & & $1139.4 \pm 82.7$ & 9 & & $112.7 \pm 5.1$ & & $397.8 \pm 27.5$ & $75.7 \pm 3.6$ \\
\hline 2018 & 18 & $826.1 \pm 73.6$ & $\begin{array}{c}166.8 \pm 11 \\
4\end{array}$ & $2.0 \pm 0.14$ & $110.0 \pm 4.5$ & 17 & $413.1 \pm 27.1$ & $81.6 \pm 3.6$ \\
\hline 2019 & 19 & & $168.3 \pm 11$. & $2.1 \pm 0.14$ & & 22 & & \\
\hline & & $718.7 \pm 74.7$ & & & $100.4 \pm 4.6$ & & $398.6 \pm 23.6$ & $80.4 \pm 3.1$ \\
\hline 2020 & 20 & $777.8 \pm 118.5$ & $167.1 \pm 18$ & $2.1 \pm 0.22$ & $106.6 \pm 7.3$ & 7 & $345.2 \pm 41.0$ & $69.7 \pm 5.5$ \\
\hline Sig. & & $* * *$ & Ns & $* * *$ & Ns & & $* *$ & ns \\
\hline
\end{tabular}




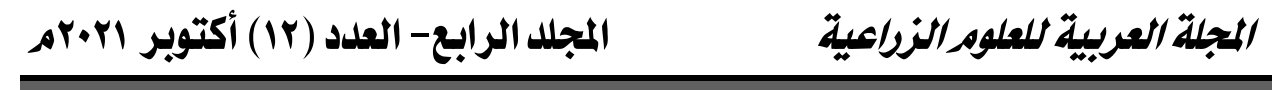

$*=\mathrm{p}<0.05$ or $* *=\mathrm{p}<0.01$ or $* * *=\mathrm{p}<0.001$ and $\mathrm{ns}=$ nonsignificant .

\section{Genetic parameters:}

\section{Variance components and heritability:}

Variance components and estimated heritability genetic covariance for productive and reproductive traits are shown in Table 4. Estimates of genetic variance $\left(\mathrm{v}_{\mathrm{a}}\right)$ for TMY, LP, NSC, DO, CI, and DP were 0.18, 0.15, 0.029, 0.24, 894.9 and 15.3 respectively. Abd-El hamid (2018) found that estimates of additive genetic variance MY, LP and DO were 2.31, 2.82 and 3.18 respectively, for Baladi cows

Heritability $\left(\mathrm{h}^{2}\right)$ estimated of TMY, LP, NSC, DO, CI, and DP were $0.18 \pm 0.01,0.15 \pm 0.001,0.07 \pm 0.016,0.05 \pm 0.001$, $0.09 \pm 0.041$ and $0.09 \pm 0.001$ respectively, which is low heritability for reproductive traits. Perez-Cabal and Alenda, (2003).Values obtained for production traits were higher than $h^{2}$ used in the official genetic evaluations for milk production traits. Short and Lawler, (1992); Smith et al., (1998).Furthermore, the values of phenotypic variance $\left(\mathrm{V}_{\mathrm{p}}\right)$ for the study traits were $1.03,0.97,0.408,0.53,9551.6$ and 165.2 respectively, while Abd-Elhamid (2018) found that estimates of phenotypic variance for MY, LP, CI and DO were 8.96, 10.00, 12.11 and 11.74 respectively, for Baladi cows. In this respect, additive genetic variance $(\mathrm{Va})$ for the studied traits was less than the residual variance $\left(\mathrm{Ve}^{2}\right)$ of the total variance ratio. According to the previous studies, it is clear that most of the reproductive traits had a very low heritability estimate. Therefore, the genetic improvement of these traits is not feasible and the improvement of these traits depends on good management systems AbdElhamid(2018). 


\section{Genetic Parameters for Milk.. $[/ \quad$ Safaa Sanad-M. Gharib}

\section{Table 4.Variance components and heritability for study}

traits on pure Baladi cows.

\begin{tabular}{|ccccccc|}
\hline & TMY & LP & NSC & DO & CI & DP \\
\hline $\mathrm{Va}$ & 0.18 & 0.15 & 0.029 & 0.240 & 894.9 & 15.3 \\
$\mathrm{Vc}$ & 0.13 & 0.01 & 0.024 & 0.024 & 520.4 & 14.6 \\
$\mathrm{Ve}$ & 0.72 & 0.72 & 0.355 & 0.48 & 8136.3 & 135.4 \\
$\mathrm{Vp}$ & 1.03 & 0.97 & 0.4078 & 0.53 & 9551.6 & 165.2 \\
$\mathrm{~h}^{2}$ & $0.18 \pm 0.01$ & $0.15 \pm 0.001$ & $0.07 \pm 0.016$ & $0.05 \pm 0.001$ & $0.09 \pm 0.041$ & $0.09 \pm 0.001$ \\
$\mathrm{C}^{2}$ & $0.13 \pm 0.02$ & $0.10 \pm 0.001$ & $0.059 \pm 0.022$ & $0.045 \pm 0.001$ & $0.054 \pm 0.04$ & $0.088 \pm 0.001$ \\
$\mathrm{e}^{2}$ & $0.70 \pm 0.01$ & $0.71 \pm 0.001$ & $0.87 \pm 0.025$ & $0.91 \pm 0.001$ & $0.85 \pm 0.07$ & $0.82 \pm 0.001$ \\
\hline
\end{tabular}

$\mathrm{Va}=$ Additive genetic, $\mathrm{Vp}=$ Permanent environmental, $\mathrm{e}=$ environmental, $\mathrm{Vp}=$ Phenotypic variance effect, $\mathrm{h}^{2}=$ heritability.

Breeding value for cows was high for studied traits. The ranges of $\mathrm{BV}$ for $\mathrm{TMY} / \mathrm{kg}$, LP/ day, NSC/services, DO/day, $\mathrm{CI} /$ day and DP/day were $776.25,26.65,6.67,13.4,78.22$ and 11.5 , respectively. In this study, the cows breeding value was positive for all studied traits. The estimated predicted breeding values (PBV) for all traits varied widely.

\section{Estimates of breeding values (BV):}

The breeding values and genetic trend are presented in Table 5 and Figure 1 and 2 respectively. The estimates of breeding values (BVs) of the studied traits vary widely. Also, the genetic trend of cow breeding value (CBV) are significant for all study traits shown in (figures 1 and 2), which indicated that the selection programs were applied for these herds. Safaa and Hassananen(2019). Also, Abd-El hamid (2018) found positive genetic trend for milk traits in cows and obtained Breeding value (BV) for cows which was high of studied traits, while AbdElhamid (2018) obtained that high Breeding value for most of studied traits. The ranges of breeding values of cows for $\mathrm{MY} / \mathrm{kg}$, LP/day, CI/days and DO/day were 583, 25.5, 107 and 92.6 days respectively. Breeding value (BV) for sires was 314, 109, 127 and 90.8 days respectively and Breeding value (BV) for dams was 258, 90, 78.7 and 74.2 days respectively, in Native Egyptian dairy cattle. 


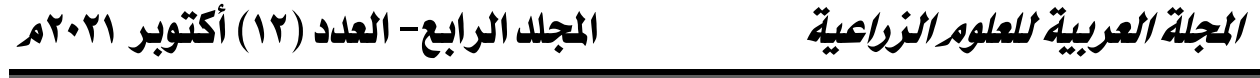

Table 5. Minimum, Maximum, BV, SE, accuracy and Range of predicted BV of studied

traits in pure Baladi cows..

\begin{tabular}{|c|c|c|c|c|c|c|c|}
\hline & \multicolumn{3}{|c|}{ Minimum } & \multicolumn{3}{|c|}{ Maximum } & \multirow[t]{2}{*}{ Range } \\
\hline & $\mathrm{BV}$ & $\mathrm{SE}$ & Accuracy & BV & $\mathrm{SE}$ & Accuracy & \\
\hline \multicolumn{8}{|c|}{ Cow } \\
\hline TMY & -343.55 & 0.29 & 0.74 & 432.70 & 0.27 & 0.77 & 776.25 \\
\hline LP & -14.94 & 9.12 & 0.57 & 11.71 & 9.26 & 0.55 & 26.65 \\
\hline NSC & -0.25 & 0.13 & 0.63 & 0.42 & 0.13 & 0.64 & 6.67 \\
\hline DO & -7.30 & 0.13 & 0.54 & 6.07 & 0.12 & 0.60 & 13.37 \\
\hline $\mathrm{CI}$ & -9.97 & 0.33 & 0.52 & 68.25 & 0.32 & 0.57 & 77.12 \\
\hline DP & -7.25 & 2.87 & 0.57 & 4.23 & 2.66 & 0.65 & 11.48 \\
\hline \multicolumn{8}{|c|}{ Sire } \\
\hline TMY & -149.04 & 0.30 & 0.71 & 378.84 & 0.27 & 0.78 & 527.88 \\
\hline LP & -10.50 & 8.29 & 0.66 & 10.01 & 8.37 & 0.66 & 20.51 \\
\hline NSC & -0.20 & 0.14 & 0.62 & 0.22 & 0.11 & 0.57 & 0.42 \\
\hline DO & -3.16 & 0.13 & 0.55 & 5.54 & 0.13 & 0.52 & 8.7 \\
\hline CI & -8.63 & 0.32 & 0.58 & 32.86 & 0.31 & 0.60 & 41.49 \\
\hline DP & -4.21 & 2.83 & 0.58 & 3.44 & 2.68 & 0.64 & 7.65 \\
\hline \multicolumn{8}{|c|}{ Dame } \\
\hline TMY & -124.13 & 0.33 & 0.62 & 552.70 & 0.26 & 0.78 & 676.83 \\
\hline LP & -10.62 & 9.38 & 0.53 & 5.70 & 9.62 & 0.50 & 16.32 \\
\hline NSC & -0.20 & 0.13 & 0.65 & 0.31 & 0.13 & 0.67 & 0.51 \\
\hline DO & -7.13 & 0.13 & 0.58 & 3.83 & 0.13 & 0.50 & 10.96 \\
\hline CI & -9.39 & 0.33 & 0.62 & 52.39 & 0.31 & 0.59 & 61.78 \\
\hline DP & -4.56 & 2.79 & 0.60 & 4.23 & 2.66 & 0.6 & 8.79 \\
\hline
\end{tabular}

Range $=($ Maximum - Minimum $)$.

\section{Genetic trend}

The purpose of the genetic trend (GT) study was to increase genetic merit for total milk yield and to determine the effectiveness of using breeding and genetic programs. Thus, the genetic trends in Native Egyptian dairy cattle must be monitored. The annual genetic trends for TMY, LP, NSC, DO, CI, and DP are shown in Figures 1-6.

Total milk yield trait was found to be affected by from year to year due to generation differences throughout the years; there was a negative trend during the 1998, 1999, 2015, 2016 and 


\section{Genetic Parameters for Milk.. $[/$ Safaa Sanad-M. Gharib}

2020, while the remaining years gave positive genetic trend at most Genetic trends of cows for TMY, relatively highly compared to their sires and dams figure 1. This indicates the absence of a clear genetic trend of the influence of years on the TMY for cows, their dams, and their Sirs. The same trend was reported by Safaa Sanad and Hassananen (2019) and Safaa Sanad and Gharib(2020). Total milk production is affected by the year of birth, and this is due to the difference in environmental conditions from year to year. It is noticed that the genetic direction of cows and sires has been determined for TMY and it has been evident that years have an effect on the genetic trend, as there was a positive trend during the period 2001-2006, 2011 and 2013. Genetic orientation of the total milk production trait is affected by the year. There was a positive (GT) during 2001-2008, 2013-2014 (figure 1). Similar results were reported by Silva et al. (2001); Ferreira et al. (2006) and Canaza-Cayo et al (2016). The same genetic trend of sires and dams of cow was found LP, NSC, DO, CI and DP traits.

In general, the influence of the year is considered one of the most important sources of variation that lead to the different traits study TMY, LP, NSC, DO, CI and DP which may be due to changes in environmental, management and nutrition systems as the impact of year of calving affects the difference in the quality of food provided to animals during the different seasons of the year. The genetic value of all studied traits was lowest for the genetic trend in 1998 and 2020 while the highest values of the genetic trend of most traits were in 2006 and 2008. CanazaCayo et al. (2016). The study concluded that the use of the designed genetic program had a positive and direct effect on the productive performance of the herd against the environmental trend.

Inter-bull trend validation methods were used to verify that estimates of GT based on traditional PBV were accurate and that 
BV was not over-estimated. Boichard et al (1995). The first test compares the GT in official evaluations that include data from multiple lactation with evaluations that include TMY traits data, and estimates of GT should be similar for both. The second method compares estimates from subsequent evaluations to determine that BV. The PBV for milk traits is calculated without bias, and the addition of daughter data overtime should not change the average PBV. Adriana et al (2016).

This decline may be attributed to the use of natural insemination and the lack of clear genetic improvement and plans for breeding. The genetic trends of cow breeding values (CBV) were significant for all studied traits. This confirms that the genetic improvement of these traits leads to increase milk production traits.

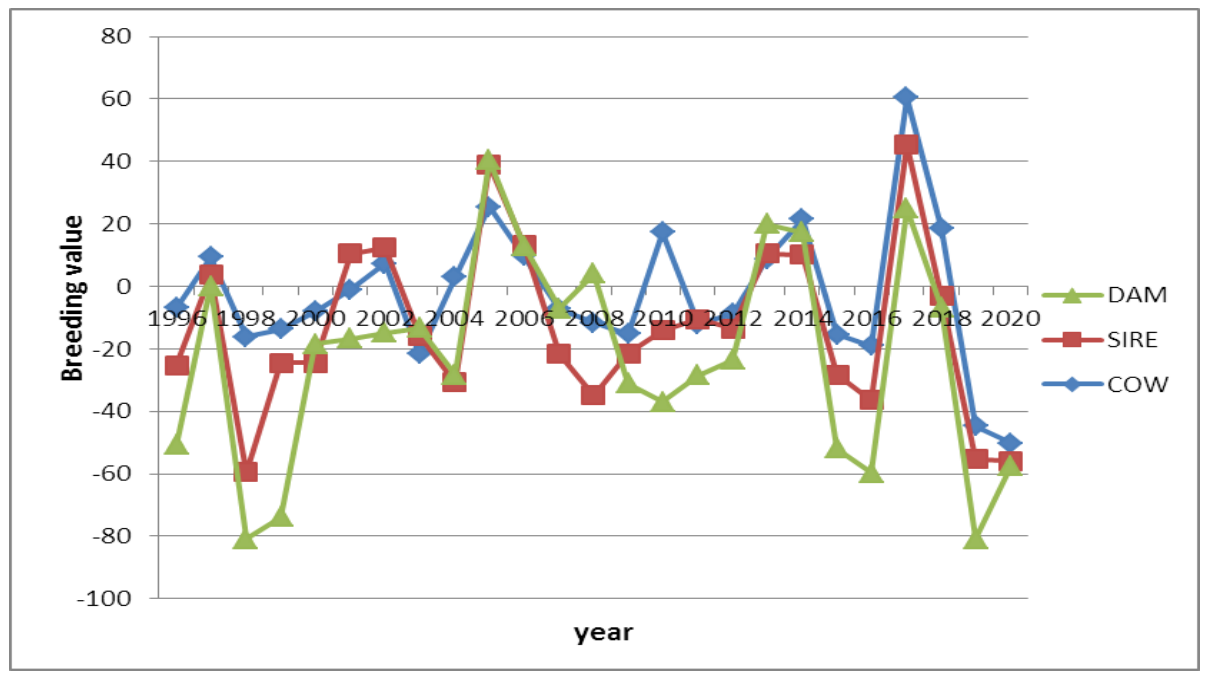

Figure 1. Genetic trend of breeding values (Dam, Sire and Cow) for TMY in Native Egyptian dairy cattle 


\section{Genetic Parameters for Milk.. $/] \quad$ Safaa Sanad- M. Gharib}

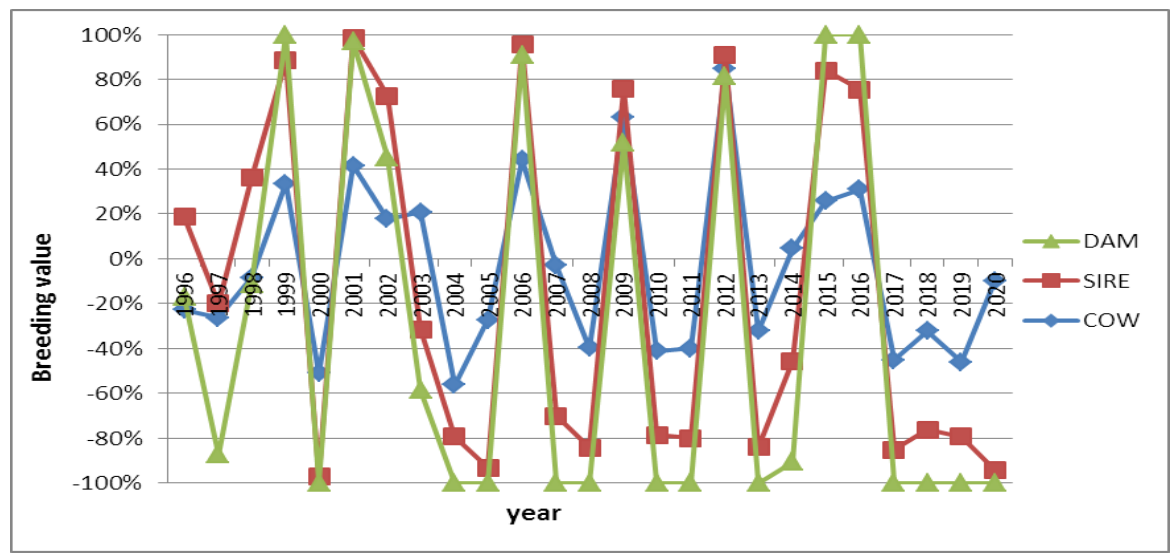

Figure 2. Genetic trend of breeding values (Dam, Sire and Cow) for LP in Native Egyptian dairy cattle

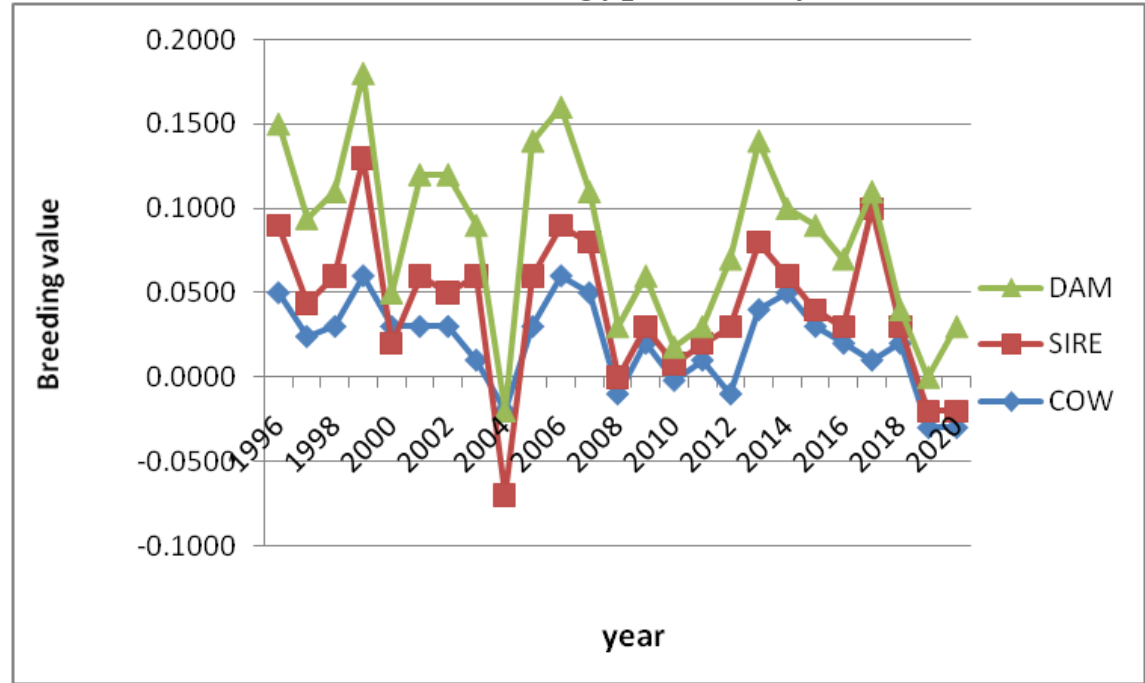

Figure 3. Genetic trend of breeding values (Dam, Sire and Cow) for NSC in Native Egyptian dairy cattle 


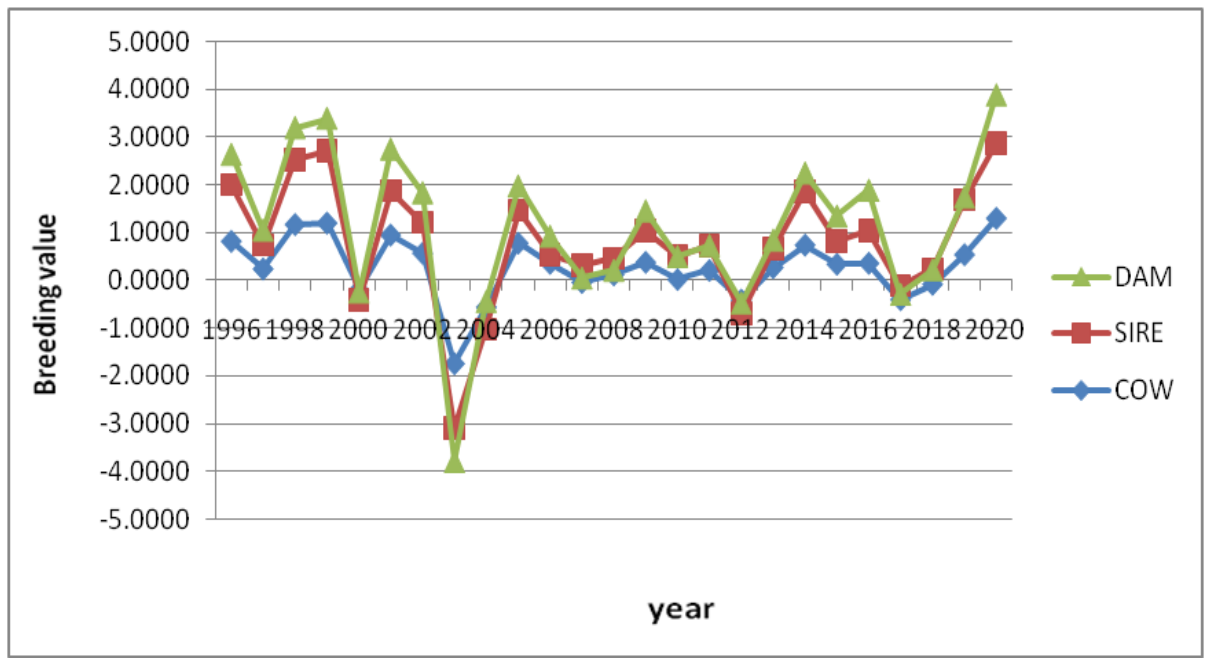

Figure 4. Genetic trend of breeding values (Dam, Sire and Cow) for DO in Native Egyptian dairy cattle

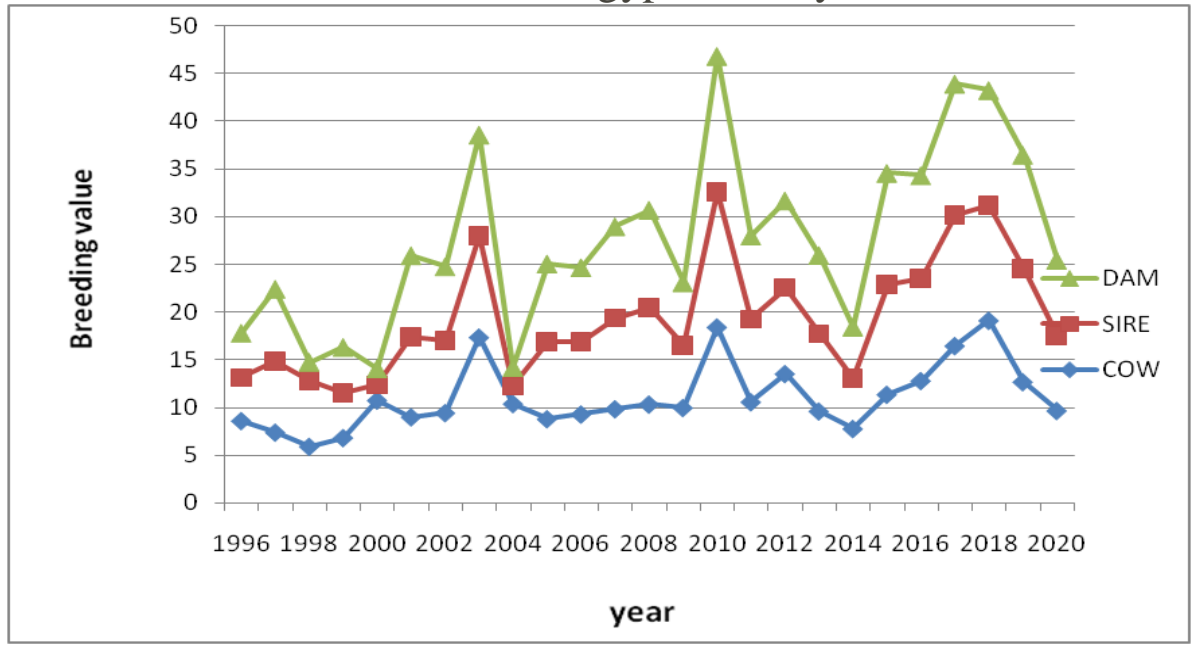

Figure 5. Genetic trend of breeding values (Dam, Sire and Cow) for CI in Native Egyptian dairy cattle 


\section{Genetic Parameters for Milk.. $[/$ Safaa Sanad-M. Gharib}

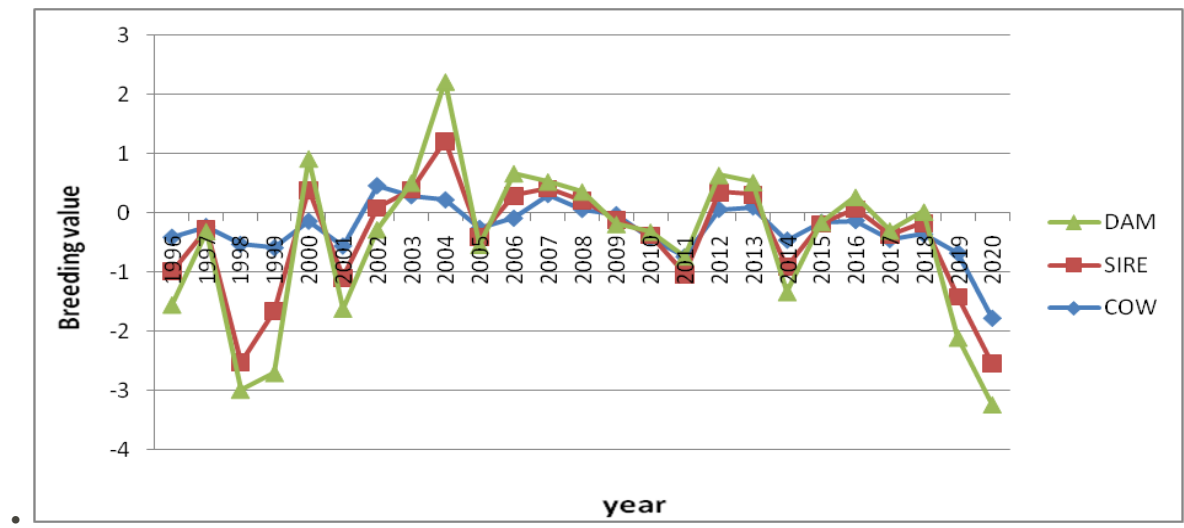

Figure 6. Genetic trend of breeding values (Dam, Sire and Cow) for DP in Native Egyptian dairy cattle

Genetic progress in Native Egyptian dairy cattle has been considerable, although it is so slow compared with previous reports.

I suggest that genetic improvement programs and proper management practices be implemented. There is the need of tracking the results to evaluate their progress to achieve the desired goal of optimizing genetic gain and increasing farm animal profitability in the future.

\section{CONCLUSION}

In conclusion, Egyptian cows are low in milk production (791 kg) with a short lactation period (171day). The amount of milk varies during the production years, which means the need to implement an effective breeding program. The positive significance of the genetic trend of cow breeding value for milk traits indicates the possibility of carrying out the genetic improvement of this trait.

The study recommends preserving the Egyptian cattle (Native Egyptian dairy cattle) because they represent a national wealth that must be preserved from extinction through inventorying the genetic resources, characterization, and evaluation of this local breed to benefit from it in improving animal breeds of high 
economic value. This is due to the distinction of Egyptian domestic cows for their resistance to various environmental conditions. 


\section{Genetic Parameters for Milk.. $[/ \quad$ Safaa Sanad-M. Gharib}

\section{REFERENCES:}

Abd-Elhamid (2018) Evaluation of reproductive and productive performance for Friesian, crosses and local cows under Egyptian condition. Thesis PhD Faculty of Agriculture Kafr el sheikh University.

Adriana García- Ruiza, b, John B. Coleb, Paul M. Van Radenb, George R. Wiggansb, Felipe J. Ruiz-Lópeza, and Curtis P. Van Tassellb,1 (2016) Changes in genetic selection differentials and generation intervals in US Holstein dairy cattle as a result of genomic selection Adriana García- Van Tassellb,1 PNAS | Published online June 27, 2016 | E3995-E4004.

Amimo, J.O , J.W. Wakhungu, B.O. Inyangala and R.O. Mosi, (2007). The effects of non genetic factors and estimation of genetic and phenotypic parameter and trends for milk yield in Ayrshire cattle in Keneya. Livestock Res. Rural Development, 19(1):1-9.

Amr .M .A. (2013). Evaluation of performance of some dairy herds in Egypt $\mathrm{PhD}$.Thesis Face .Agaric . Alexandria Universe . Egypt

Arafa, Samira. A. (1987). The effect of crossing Egyptian cattle with exotic breeds on some productive traits. M.Sc. Thesis, Fac. of Agric., Mostoher, Zagazg. Univ., Egypt.

Boichard D, Bonaiti B, Barbat A, Mattalia S (1995). Three methods to validate the estimation of genetic trend for dairy cattle. J Dairy Sci 78(2):431-437.

Boldman, K. G.; Kriese L. A.; Van Vleck L. D. and Kachman S. D. (1995). A manual for use of MTDFREML.A set of programs to obtain estimates of variances and covariances (DRAFT). ARS, USDA, Washington, D. C.

Canaza-Cayo,A.W. Jaime,A.C and Paulo.S L.(2016) Genetic trend estimates for milk yield production and fertility traits 
of the GI Rolando cattle in Brazil . Livestock Science 190 (2016) 113-122.

El-Awady, H.G. and E.Z.M. Oudah (2012).Effect of some non-genetic factors on milk yield and calving interval of Friesian cows.Minia International Conference for Agriculture and Irrigation in the Nile Basin Countries, ElMinia, Egypt.

El-Shabory, L.S.(2009).A study of productive traits on Egyptian cattle and it is crosses with Friesian cattle. M.Sc., Thesis, Fac. of Agric. Tanta Univ., Egypt.

Ferreira,W.J.,Teixeira,N.M.,Torres,R.A.,Barra,R.B.,(2006).E stima çãodetendência genetic apara produçã odeleitenaraça Holande sanoestado de Minas Gerais. Arq.Bras.Med.Vet.Zootec.58(4),599-606.

Katkasame, S., Tumwasorn, S., Thaninndratarn B. and S. Pasanpanich (1996).Trend analysis on milk production traits in the dairy farming promotion organization of Thailand. Kasetsart J. Nat. Sci., 30: 211-219.

Khalifa, Zeinab. A. (1994).Effect of crossing Native cattle with Friesian on milk production traits in Egypt. Ph.D. Thesis, Fac of Agric., Alexandria Univ., Egypt.

Ojango, J.M. and G.E. Pollott(2001).Genetic of milk yield and fertility traits in Holstein-Friesian cattle on large-scale Kenyan farms. J. Anim. Sci.,79:1742-1750.

Ozkan, M.; and H. Gunes (2011). Effects of some factors on milk yield characteristics of Simmental cows on commercial farms in Kayseri. J. Fac. Vet. Med. Istanbul Univ., 37:81-88.

Pantelic, V.; D. Ruzic-Muslic; and M.M. Petrovic (2013).The phenotypic variability of production traits in the population of Simmental cows. 2013. In: international symposium modern trends in livestock production, 10, Serbis. 


\section{Genetic Parameters for Milk.. $[/$ Safaa Sanad-M. Gharib}

Pantelic, V.; M.M. Petrovic; and D. Ostojic-Andric (2014).The effect genetic and non-genetic factors on production traits of Simmental cows.Biotechnol. Anim. Husbanday. 30(125): 251-260.

Perez-Cabal M. A. and R. Alenda( 2003).Lifetime Profit as an Individual Trait and Prediction of its Breeding Values in Spanish Holstein Cows J.Dairy Sci. 86:4115-4122

Petrovic, D.M.; V. Bogdanovic; and M. Petrovic (2015).Effect of non-genetic factors on standard lactation milk performance traits in Semmental cows. Ann. Anim. Sci., 15: 211-220.

Safaa.S.Sanad, (2016)Genetic improvement using the selection indices for some productive and reproductive traits in Friesian cattle raised in Egypt J. Anim. and poultry Prod ., Mansoura Univ., Vol 7 (12) : 475-482 .

Safaa,S.Sanad and M.G.Gharib, (2020). Estimation of the genetic and environmental trends for milk traits of Holstein herd. Egypt. J. Agric. Res., (2020), 98 (1), 397-409.

Safaa .S. Sanad and Hassanane, M.S. (2019)Genetic factors affecting total milk yield, lactation period and calving interval of Crossbred Friesian cows raised on Nile Delta. Egypt. J. Agric. Res., 97 (2), 2019:771-784.

Safaa S. Sanad*; M. G .Gharib ; M. A. E. Ali and A. M. Farag (2021). Prediction of Milk Production of Holstein Cattle Using Principal Component Analysis . J. of Animal and Poultry Production, Mansoura Univ., Vol 12 (1):1 -5, 2021

SAS, (2003).User's guide: Statistics, version 9.4th Ed. SAS Ins., Inc., Cary., NC, USA.

Short, T. H., and T. J. Lawlor.(1992). Genetic parameters of conformation traits, milkyield, and herd life in Holsteins. J. Dairy Sci. 75:1987-1998. 
Silva,M.V.G.B.,Ferreira,W.J.,Cobuci,J.A.,Guaragna,G.P.,Oli veira,P.R.P.,(2001). E-estimativas de tendência genética para características produtiva sem rebanho do ecótipo Mantiqueira 30:1466-1475, Rev.Bras.Zootec.

Smith, L. A., B. G. Cassell, and R. E. Pearson (1998). The effects of inbreeding on the lifetime performance of dairy cattle. J. Dairy Sci. 81:2729-2737. 
Genetic Parameters for Milk.. $[\quad$ Safaa Sanad-M. Gharib 